\title{
A Fair Value and Hedge Activities
}

\section{Doan Van Dinh ${ }^{1 *}$ and Guangming Gong ${ }^{2}$}

${ }^{1}$ College of Economics and Trade Management of Hunan University, China and Faculty of Finance and Banking of the Industrial University of Ho Chi Minh City, Vietnam ${ }^{2}$ Business school Hunan University in China

\begin{abstract}
This article, author consider the fair value of financial instruments whether it is appropriate for economic development and the volatility of the stock market or not through investors' financial statement analysis and to help the Managers, Investors and someone else understand about reasonable economic information in financial statements. Because, Use of fair Value method plays an important role in measurement of financial instruments and help entity can decrease risk financing. However, Vietnam entities have not applied fair value method yet to revalue financial assets. So value financial assets in financial statements are not exact. This problem impacts on Vietnam financial market for long time. This article shall consider the fair value and historical cost methods measure financial instruments on the stock market through economic transactions to find out the difference of value financial assets, when using two these method to revalue them. The usage of fair value measurement accounting is a necessary factor for the development of Vietnamese stock market. Currently, Vietnamese accounting is using a book method for financial instruments; besides that the fair value accounting has not been thoroughly applied by entities under the standards of international financial instruments accounting.
\end{abstract}

Keywords: Fair value; Historical cost; Financial statements; Financial instruments; Financial statements

\section{Introduction}

When financial assets are transacted by firms, the value of financial assets will be varied from the market price. Therefore, the companies need to apply fair value method to measure them, and ensure that the value of financial assets appropriate real value of assets [1]. Because, information on financial reports play an important role in managers and investors to analyze the accounting data give reliable results, and this information Results as a basis for making management decisions or investing in the stock market. As we see, historical cost is determined the initial value of investment securities and recognition in accounting books, after that value of the securities will be varied according to the market price. Therefore, the historical cost of the securities will be unreasonable in the future. So the firms need to apply fair value method for their value revaluation [2]. In addition, using the fair value method to measure financial assets will help managers, investors avoid financial risks. The IASB'S researches show that the economic crisis is affected by financial risks. Specifically, in 2008 the economic crisis started from the economy of the U.S. and then it spread out the global economy. This economic crisis was due to bad debt credits and frozen properties investment. Besides, the accounting method is also an important factor and impact on the relevance and reliability of Financial Statements. If the accountants apply inexact accounting method, it will lead to inexact financial information in Financial Statements.

So the International Accounting Standard Board (IASB) has issued international accounting standards (IAS), such as IAS 32 (Financial Instruments: Presentation); IAS 39 (Financial Instruments: Recognition and Measurement); international financial reporting standard (IFRS 7 - Financial Instruments: Disclosures) [3] and international financial reporting standard (IFRS 9 - Financial Instruments) for firms' application.

From the above reasons, the author considers the relevance and reliability of Vietnam's current Financial Statements and finds out that when the firms apply the inexact accounting method to evaluate the financial assets, their financial statements will be irrelevant and unreliable. In fact, almost foreign investors and domestic investors don't dare to make more investment on Vietnam stock market. They doubt about the relevance and reliability of Financial Statements. Because, they cannot understand accounting method that the firms have applied to make financial statements. So, they cannot identify that the accounting data in financial statements are exact or inexact. Although the financial statements were audited by auditors, auditor's audit statements are the only reference for the Investors. So they can get risk financial information. Why? This problem needs to discuss, and find out unreasonable financial information or reasonable financial information on Financial Statements. In 2000 the stock market of Vietnam officially went into operation with the operation of the Stock Exchanges in Ho Chi Minh City on July 20, 2000 and in Hanoi on March 8, 2005. But, the Vietnam Stock Exchanges have not been developed for 11 years yet ${ }^{1}$ (Vietnam stock market loses over $\$ 10 \mathrm{~b}$ of capitalization in 2011). The author assesses the irrelevance and unreliability of financial statements whether it impacts on the Decline of Vietnamese stock market or not and why? Besides, the Vietnam accounting policy is also a factor to make an impact on the Vietnamese stock market. Because, from 2001 to now, the Vietnamese Ministry of Finance issued 26 Vietnamese Accounting Standard (VAS) include: VAS 1- General provisions, VAS 2- Inventories, VAS 3- Property, VAS 4- Intangible Assets, VAS 5Investment Property, VAS 6- Leases, VAS 7- Investments in Associates, VAS 8- Interests in Joint Ventures, VAS 10- The Effects of Changes in Foreign Exchange Rates, VAS 11- Business Combinations, VAS 14Revenue, VAS 15- Construction contracts, VAS 16-Borrowing Costs, VAS 17- income tax, VAS 18- Provisions, Contingent Liabilities and

http://en.stockbiz.vn/News/2012/1/3/262166/vietnam-stock-market-loses-over10b-of-capitalization-in-2011.aspx

*Corresponding author: Doan Van Dinh, College of Economics and Trade Management of Hunan University, China and Faculty of Finance and Banking of the Industrial University of Ho Chi Minh City, Vietnam, Tel: +84.978624215; +86.13507468015, E-mail: citydinhninh@yahoo.com

Received March 18, 2013; Accepted April 18, 2013; Published April 24, 2013

Citation: Dinh DV, Gong G (2013) A Fair Value and Hedge Activities. J Bus \& Fin Aff 2:108. doi:10.4172/2167-0234.1000108

Copyright: ( 2013 Dinh DV, et al. This is an open-access article distributed unde the terms of the Creative Commons Attribution License, which permits unrestricted use, distribution, and reproduction in any medium, provided the original author and source are credited. 
Contingent Assets, VAS 19- Insurance Contracts, VAS 21- Presentation of Financial Statements, VAS 22- Financial Instruments: Disclosures, VAS 23- Events after the Reporting Period, VAS 24- Statement of Cash Flows, VAS 25- Consolidated and Separate Financial Statements, VAS 26- Related Party Disclosures, VAS 27- Interim Financial Reporting, VAS 28- Operating Segments, VAS 29- Accounting Policies, Changes in Accounting Estimates and Errors, Plant and Equipment, VAS 30 Earnings per Share.

The financial instrument accounting standards play an important role in the measurement and classification of financial instruments. However, the Ministry of Finance has not issued them yet. So the Vietnamese firms are applying the historical cost method to recognize value of financial assets, leading to affect the relevance and reliability of Financial Statements [4].

\section{The Rationale for Fair Value}

Currently, it is very difficult to measure fair value of the assets because there have not been any measurement standard to evaluate them. Because of the fair value measurement based on the market, that is not an entity specific measurement. Therefore, measurement of fair value should be determined based on the assumptions that the market would use in pricing the asset or liability. According to the definition of the fair value (paragraph 5) in Statement of Financial Accounting Standards 157 (SFAS 157) as "the price that would be received if an asset is sold or paid to transfer a liability in an orderly transaction between market participants at the measurement date". In case of fair value measurement, the firms should base on the market price or the other methods to evaluate their assets. Generally accepted accounting principles (GAAP) U.S give three methods of determining the assets that are the market approach, income approach, and/or cost approach. The market approach is "The market approach uses prices and other relevant information generated by market transactions involving identical or comparable assets or liabilities (including a business)". The income approach is "The income approach uses valuation techniques to convert future amounts (for example, cash flows or earnings) to a single present amount (discounted). The measurement is based on the value indicated by current market expectations about those future amounts" and the cost approach is "The cost approach is based on the amount that currently would be required to replace the service capacity of an asset (often referred to as current replacement cost). From the perspective of a market participant (seller), the price that would be received for the asset is determined based on the cost to a market participant (buyer) to acquire or construct a substitute asset of comparable utility, adjusted for obsolescence".

The Fair Value Accounting is based on International Accounting Standard (IAS 39 - financial instruments: recognition and measurement), Fair value is defined as "the amount for which an asset could be exchanged, or a liability settled, between knowledgeable, willing parties in an arm's length transaction" (paragraph 9) [5]. Underlying the definition of fair value in IAS 39, International Accounting Standards Board (IASB) gives also three approaches: Market approach, Income approach and Cost approach. Besides, the market approach is observable market prices and information on actual market transactions will be used to estimate the fair value of an asset, a liability; the income approach is the technical approach and will be applied to convert the funds in the future on the present value. (The money from the exploitation and use of assets or cash flow to pay liabilities) and the cost approach is the fair value of an asset and is determined on the basis of considering the cost incurred to obtain an equivalent replacement asset to manufacturing capacity (cash flow to spend to buy production assets). However, within the scope of this article, the author shall deal with a market approach (quoted prices) to evaluate securities and to find out their effects.

The fair value is only an evaluation method, thus the firms can base on IAS 39 or SFAS 157 to choose a suitable measurement method to evaluate the financial assets for financial hedging activities. Before the firms choose the measurement method, the financial assets need to be classified. From the classification of financial assets, the firms can use the method of asset valuation simply and exactly. According to Measurement of Financial Instruments and Recognition of Gains and Losses in International Financial Reporting Standard (IFRS 9 Financial Instruments) as Assets under [6]:

-Loans and receivables and Held-to-maturity investments are measured by amortized cost method, and then they are recognized in net income when the asset is derecognized or impaired (foreign exchange and impairment are recognized in net income immediately).

-Available-for-sale financial assets and Held for trading are measured by Fair value method. But Available-for-sale financial assets are recognized in other comprehensive income (impairment is recognized in net income immediately) and Held for trading are recognized in Net income immediately.

\section{The Rationale for Historical Cost}

Assets are recognized at cost. Cost of assets is recognized by cash or cash equivalents paid payable or evaluated under the fair value of the asset on that date. The original cost of the assets cannot be changed (except) the other regulations in the specific accounting standards. The cost of inventories includes purchase costs, processing costs and other direct costs associated with inventory. Historical cost of assets is used for the initial recognition in the financial statements and to compare its value variable on the market, and is the base for calculating the Gains and losses in income statements. Recognition principle of the historical cost is as follows: all assets need recognizing their historical cost of the assets.

Underlying the definition in IAS 32, cost is defined as follows [7]:

\section{Inventories are assets}

a. Held for sale in the ordinary course of business;

b. In the process of production for such sale; or

c. In the form of materials or supplies to be consumed in the production process or in the rendering of services. And Net realizable value is the estimated selling price in the ordinary course of business less the estimated costs of completion and the estimated costs necessary to make the sale. Fair value is the amount for which an asset could be exchanged, or a liability settled, between Knowledgeable, willing parties in an arm's length transaction. This case, the firm needs to determine the inventory value according to two measurement methods that are net realizable value and fair value of the inventory. Underlying also the definition in IAS 2, the inventory's value needs to be evaluated in the process of business, when their values are variable in the market. The assumptions that: firm purchased 2,000 shares, at $\$ 10$ per shares in $31 / 3 / \mathrm{N}$, and the firm paid cash. The next month hypothesis, the firm sell 2,000 shares with selling price $\$ 12$ per share. On $31 / 12 / \mathrm{N}$, in case, the firm has not sold securities and then the market price can increase or reduced. Meanwhile, the inventory stock value of the firm will be variable; assuming that the stock price drops $\$ 8$ per share, the firm loses $\$ 2$ per share. Now, the firm needs 
to adjust the value of securities at fair value. In case, the firm doesn't adjust the historical cost of the securities they will be irrelevant on the balance sheet. So, historical cost is irrelevant longer. Therefore, assets on the balance sheet are recorded at historical costs until sold (Table 1).

\section{Cost-based IFRS measures}

According to international accounting standards IFRS the historical-cost method is stated in different standards for different accounting objects such as [8-14]:

- Few things measured at historical cost:

- Unimpaired land (IAS 16 + IAS 40 cost model)

- Unimpaired indefinite life intangibles (IAS 38)

- Unimpaired inventories (IAS 2)

Cost-based measures are more common

- Unimpaired depreciated historic cost (IAS 16)

- Unimpaired amortized historical cost (IAS 38)

- Amortized cost (IFRS 9)

Through the guidelines of international accounting standards given above, show that recording assets at historical cost right after being purchased is essential in ensuring accuracy of the property after formation. However, the asset value will change over time and be influenced by factors of market value, if assets are still recorded at the historical cost, then the asset value is unsuitable to be recorded and mentioned in the financial statements to be presented by the enterprise. Hence it is inevitable that the original value of assets needs to be replaced by the fair value. The international accounting standards have well adopted the measurement and recognition of assets at the fair value to match the current assets (Table 2) [15].

\section{The System of Vietnamese Accounting Standards}

The Vietnamese accounting standards are not much different from international accounting standards, particularly for accounting standards of inventory. However, the standards IAS 16, IAS 38 and VAS 3, VAS 4 have basic differences; these differences lead to differences between information on Vietnam's financial statements and international financial statements. Additionally, the Accounting Standards System of Vietnam lacks some basic standards for the financial instruments of accounting, which is the reason why fair value methods are not being applied for calculating assets on the financial statements of Vietnam [16].

Presently, the financial statements of Vietnam still apply the historical cost method, in the case of decreased inventory price; it is adjusted by the provisional method. The inventory is defined by Standard No. 2 VAS 02: "The inventory is calculated at original cost. Where the net realizable value that is lower than the original cost must be calculated according to the net realizable value". For financial instruments, the Vietnamese accounting system has no financial instruments standard

\begin{tabular}{|c|c|c|c|}
\hline Date & Account and Explanation & Debits & Credits \\
\hline $31 / 3 / \mathrm{N}$ & Common securities & $\$ 20,000$ & \\
\hline Initial recognition & Cash & & $\$ 20,000$ \\
\hline \multirow{3}{*}{$\begin{array}{l}\text { Revenue - } \\
\text { Financial activities } \\
\text { recognition }\end{array}$} & Cash & $\$ 24,000$ & \\
\hline & Common securities & & $\$ 20,000$ \\
\hline & Revenue - Financial activities & & $\$ 4,000$ \\
\hline
\end{tabular}

Table 1: Sale of Equipment at Historical Cost. that can be implemented. Therefore, Vietnamese firms still apply the historical cost method by the following rules [17-23]:

1. Short-term investment securities must be recorded in the accounting books according to the actual purchase of securities (at original cost) including: purchase price $(+)$ purchase cost (if any), such as costs of brokering, transactions, information supply, tax, fee and banking fee.

2. Short-term investment securities, including long-term securities are purchased for sale in the stock market which can recover capital for a period of not more than one year.

3. At the end of the accounting year, if the market value of shortterm investment securities is lower than the original price, accounting for the value impairment of short-term investment securities.

4. The accountant must open detailed books to track each type of short-term investment securities (In each class of shares, bonds, securities with different values; under each investment partner; each type of face value and the actual purchase price).

In the case of declining stock prices, the enterprises must make provision for a reduced price at the end of the accounting year under the following principles [24-26]:

1. The appropriation and reversal of provision for value impairment of short-term investments are made at the time of closing the accounting books for presentation of the yearly financial statements. For the businesses that make the interim financial statements, if there are any big changes in provision, the appropriation or reversal of provision will be adjusted.

2. Making provision for value impairment of short-term investments is determined by the difference between the net realizable value (market value) and the historical cost recorded in the accounting books. If the amount of the provision being made in this period is higher than the provisional balance being made at the end of the previous accounting period, the difference is recognized in financial costs in the period. If the amount of the provision made this year is lower than the provisional balance been recognized in the accounting books, the difference shall be recorded at reduced price from the financial cost.

3. Conditions of appropriation of provision for value impairment of short term investments are as follows:

- The enterprises can make legal investment in securities;

- Freely being purchased and sold on the market at the time of inventory and presentation of the financial statements with the market price down as compared with the original price recorded in the accounting books (for securities that are not freely traded, cannot make provision).

4. The enterprises must make provisions for each type of shortterm investment security when fluctuations of decreased prices happen at the end of the accounting period by the following formula 1:

Provision for

decreased value Number of securities The original price of Market price of

of short-term $=$ with decreased price $\mathrm{X}$ [securities recorded in - short-term investment] investment at the end of yearly the accounting books securities securities accounting period

The enterprises must determine the amount of provision to set up for each type of short-term investment security whose price are 


\begin{tabular}{|c|c|c|c|}
\hline Asset Type & Measurement at Initial Recognition & Cost Model & Basis of Impairment Test \\
\hline IAS 2 Inventory & $\begin{array}{l}\text { Cost of purchase and/or conversion costs, } \\
\text { transportation costs and costs } \\
\text { to get the item in condition for sale }\end{array}$ & Cost unless impaired & $\begin{array}{l}\text { Lower of initial recognition cost and } \\
\text { net realizable value }\end{array}$ \\
\hline $\begin{array}{l}\text { IAS } 16 \text { Property, Plant and } \\
\text { Equipment }\end{array}$ & $\begin{array}{l}\text { Purchase costs }+ \text { construction costs }+ \\
\text { transportation costs and costs to get the item in } \\
\text { working condition as intended by management }\end{array}$ & $\begin{array}{l}\text { Accounting policy choice: cost less accumulated } \\
\text { depreciation and impairment, if any }\end{array}$ & \multirow{3}{*}{$\begin{array}{l}\text { Compare carrying amount } \\
\text { to recoverable amount. The } \\
\text { recoverable amount is greater } \\
\text { of value in use and fair value less } \\
\text { disposal costs (IAS 36) }\end{array}$} \\
\hline $\begin{array}{l}\text { IAS } 38 \\
\text { Intangibles Assets }\end{array}$ & $\begin{array}{l}\text { Purchase costs }+ \text { development costs }+ \\
\text { transportation costs and costs to get the item in } \\
\text { working condition as intended by management }\end{array}$ & $\begin{array}{l}\text { Accounting policy choice: cost less accumulated } \\
\text { amortization (unless indefinite life asset) } \\
\text { and amortization, if any }\end{array}$ & \\
\hline $\begin{array}{l}\text { IAS } 40 \text { Investment } \\
\text { Property }\end{array}$ & Cost including transaction costs & $\begin{array}{l}\text { Accounting policy choice: cost } \\
\text { less accumulated depreciation (unless land) and } \\
\text { impairment(if any) }\end{array}$ & \\
\hline IFRS 9 Financial Instruments & Fair value & For particular business models amortized cost & IAS 39 specifies impairment rules \\
\hline
\end{tabular}

Table 2: Process of Asset Measurement.

decreased and they are synthesized into a detailed provision list for the decline in security price and comparing with data made at the end of the previous accounting period to determine more provision or reversal of the reduced financial costs.

Provisions for long-term investments are made in principle as follows [27-29]:

1. The appropriation and reversal of provision for value impairment of long-term investments are made at the time of the yearly accounting period. For the enterprises who are approved by the Ministry of Finance to apply fiscal year other than the calendar year (fiscal year does not begin on January 1 and not end on December 31 every year), the time for provision is the last day of the fiscal year. For the businesses that make the interim financial statements, if there are any big changes in provision, the appropriation or reversal of provision will be adjusted at the end of the interim accounting period (quarterly accounting period).

2. The provision for value impairment of long term investments must be made in accordance with the rules of each type of long-term investment. The provision level is determined by the difference between the net realizable values (market price) or withdrawn investments and the original price recorded in the accounting books. If the amount of the provision for this year is higher than the provisional balance recorded in the accounting books, the difference shall be recognized in business \& production expenses in the period. If the amount of the provision which is made in this year is lower than the provisional balance which was made in last year but not used up, the difference shall be recorded reduction in the business $\&$ production expenses.

3. The preparation and treatment of provision for value impairment of long-term investment securities are made at the end of the fiscal year if the market price of the long-term investment securities is often lower than the original price recorded in the accounting books.

Conditions of appropriation of provisions for value impairment of long-term securities are as follows:

\section{- The enterprises make legal investment in securities;}

- Freely being purchased and sold on the market at the time of inventory and presentation of the financial statements with the market price down as compared with the original price recorded in the accounting books.

4. The enterprises must make provisions for each type of short- term investment security when fluctuations of decreased prices happen at the end of the accounting period by the following formula 2 :

Provision for decreased Number of securities with The original price of value of short-term $=$ [decreased price at $\quad \mathrm{X} \quad$ securities recorded in $]$ investment securities for presentation time of yearly the accounting books next year financial statements Market price of short -term investment securities

The enterprises must determine the amount of provisions to set up for each type of long-term investment security whose prices are decreased and then they are synthesized into a detailed provision list of declining security prices and compared with data which was formulated at the end of last year but not used up to determine more provision or reversal of the reduced financial costs.

\section{Data Analysis and the impact it has on the Relevance and Reliability of Financial Statements}

The stock market's development depends on the relevance and reliability of financial statements through investors. Therefore, the use of the historical cost method by Vietnamese firms is inappropriate because it makes a provision for impairment in asset value according to the principles mentioned above, the information in the financial statements did not reflect the nature of the assets at the time when the financial statements are presented. Below are some accounting assumptions that prove the relevance and reliability of financial statements (Tables 3-5):

\section{Using Historical cost.}

\section{Accounting assumption:}

On date 19/02/2012, the firm A bought \$ 1,555 of common stocks that are, face value of a share is $\$ 10$, brokerage fees of share are $\$ 2$. This time, current price of a share is \$20.

On date 12/8/2012, the firm sold \$555 of common stocks, current price of a share is $\$ 25$, Brokerage fees of share are $\$ 1$.

- The first case: on the 31/12/2012, Firm A with a debit balance of securities is 1,000,000 shares. This time, Current price of security is $\$ 30$.

- The second case: On 31/12/2012, Firm A has a debit balance of securities are 1,000,000 shares. Current price of Security is \$15.

Determinant of double entry is as follows:

* The amounts of 1,555,000 shares are purchased.

* The amounts of 555,000 shares are sold. 


\section{Using fair value method}

\begin{abstract}
The same Accounting assumption as above:
On date 19/02/2012, the firm A bought 1,555,000 of common stocks with a face value of a share of $\$ 10$, brokerage fees of the share is $\$ 2$.

This time, current price of a share is $\$ 20$.

On date $12 / 8 / 2012$, the firm sold 555,000 of common stocks, current price of a share is $\$ 25$, Brokerage fees of share are $\$ 1$.
\end{abstract}

- The first case: on the 31/12/2012, Firm A with a debit balance of securities is 1,000,000 shares. This time, quoted price of securities in an active market is $\$ 30$ per share.

- The second case: On 31/12/2012, Firm A with a debit balance of securities is 1,000,000 shares; quoted price of securities in an active market is $\$ 15$ per share.

\section{Solution 3}

The part of the determinant of double entry is same as a determinant of double entry of solution 1 . However, there is a different result of financial reporting as follows.

- The first case: on date 31/12/2012, the firm revalues fair value of the security base on securities debit balance when the firm forms financial reporting of accounting period.

- When a quoted price of security in an active stock market is $\$ 30$, it means that the firm needs to adjust the security's value by quoting prices in an active stock market. Now the quoted price is higher than historical cost: $(\$ 30-\$ 22)=\$ 8 ;(1,000,000$ shares $\mathrm{x}$ $\$ 8)=\$ 8,000,000$.

\section{${ }^{\star}$ Write - up.}

- The second case: When a quoted price of security in an active market is $\$ 15$ per share, that means, the firm needs to adjust the security's value by quoting prices in an active market. Now the quoted price is less than historical cost: $(\$ 15-\$ 22)=(\$ 7)$; $(1,000,000$ shares $\times \$ 7)=\$ 7,000,000{ }^{*}$ Write - down.

\section{Discussion and Conclusion of How Financial Statements} have an Impact on the Vietnamese Stock Market

\section{Discussion about the impact of the relevance and reliability of financial statements}

Problem 1: Unmatched accounting of the historical cost method: Assets which are available-for-sale and financial assets cannot use the historical cost method for recognizing and presenting the accounting year-end financial statements. Because, the security value is a type of financial asset held for trading, their value is usually a variable on the stock market. Therefore, the firms' application of this method will affect the suitability of the assets held for trading. The results of the above analysis show that when the firms use the historical cost method, the results in the income statement are inappropriate for the fair value of the assets.

- In a scenario whereby security prices increased at the time when the year-end financial statement is presented, then the security value on the market is $\$ 30$, while the security value on the balance sheet still presents the original value that is $\$ 22$. A different ratio compared with the original price is $36 \%$, the greater the difference rate is then the greater the error degree of current security's price will be, leading to the information on financial statements to have a greater difference than the actual security value at the time when financial statements are presented. This difference has clearly affected the income statement and balance sheet. For the income statement of solution 1, the business results only reflect securities trading that have already occurred, but do not reflect the actual value of inventory securities that have brought profits for the business. The security prices rise on the stock market meaning that the profits that were not achieved are also increasing but the income statement has not presented this item. The balance sheets also do not show the increased value of securities at the market price but only show retained achieved from financial activities.

- In the case of a security's price falling at the time when financial statements are presented as the above analysis depicts the security's price will drop to $\$ 15$. If the securities are sold with this price at this time, the securities shall be lost, because the market price is lower than the original price of securities. To preserve capital, according to the Vietnamese accounting system, the entities are required to make financial provision at accounting period. This financial provision level is made on the basis of the hedge accounting for financial activities, the first formula is for the provision for short-term investments and the second formula of accounting estimates is for provision for longterm investments. The above assumptions applied the first formula and got decreased and different results in the stock market compared to the original price, the decreasing rate is $32 \%$. This ratio reflects the correct fluctuation level of security prices on the stock market at the time when financial statements are presented. However, according to this method, the company made a provision appropriate for short-term investments without revaluation of fair value of securities on the stock market price. This made the stock inventory value of financial statements not change as a result of solution 2 (stock inventory value of solution 1 and the stock inventory value of solution 2 is equal to $\$ 22,000,000$ ).

The table of the income statement did not reflect the actual results from financial activities. Because at the time of securities sale, the security's price did not reduce, the business got profits. But the security's price unexpectedly fell last year, forcing the business to make a stock provision. The security provision made financial costs increase, leading to a drop in financial profits that exceed a safe level. In this case, the financial profits fell below the breakeven point; the business could not get the profits that were lost. Actually, the business still got profits of $\$ 1,110,000$ to replace the lost profits $(\$ 5,890,000)$ as expressed in the results of the income statement in solution 2. For the balance sheet, the short-term investment provision increases because the business makes provision for a decreased security's price, but the securities investment item does not change, it still remains original. Thus, the securities investment item did not reflect the true market price of the securities at the time when financial statements are presented. Specifically, the security's price at this time has dropped to $\$ 15,000,000$, instead of $\$ 22,000,000$ as an analysis result above. Although, the ultimate results of the two methods are the same and is $\$ 28,320,000$, but the items for analysis will have different results. When the retained earnings item on the balance sheet is also down, leading to a decrease of total capital source. Otherwise, the retained earnings item on the balance sheet has not been shown correctly. Because the reduced capital source is affected by the reduced value of inventory security, but profits from trading 


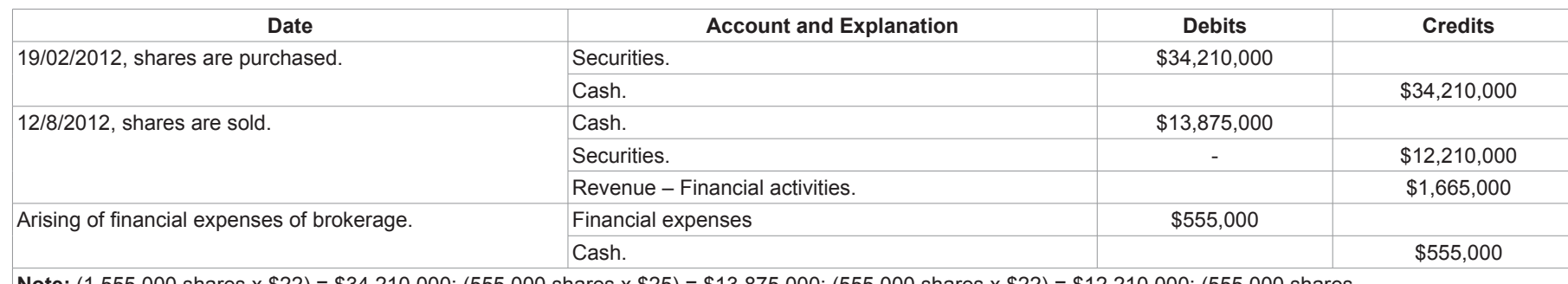

Note: $(1,555,000$ shares $x \$ 22)=\$ 34,210,000 ;(555,000$ shares $x \$ 25)=\$ 13,875,000 ;(555,000$ shares $\times \$ 22)=\$ 12,210,000 ;(555,000$ shares

$x \$ 3)=\$ 1,665,000 ;(555,000$ shares $x \$ 1)=\$ 555,000$.

The first case: on the 31/12/2012, Firm A has a debit balance of securities of 1,000,000 shares; price of security is $\$ 30$. This case, the Vietnamese accounting system states that the prices of securities are not adjusted at "market prices" when shares' prices increasing arise in the stock market.

- Debit balance of cash: $\$ 13,875,000-\$ 555,000 \$$ equal to $\$ 13,320,000$.

- Debit balance of Securities investments: $1,000,000$ shares $x \$ 22$ equal to $\$ 22,000,000$.

1. The result of income statement on $31 / 12 / 2012$ :

- Revenue - Financial activities: (1)

- Financial expenses: (2)

- Profit after Income Tax (3) = (1) - (2)
$\$ 1,665,000$

$\$ 555,000$

$\$ 1,110,000$

2. The result of Balance sheet on 31/12/2012:

\section{A. Assets:}

1) Cash:

2) Investment securities:

3) Provision for short - term investments *:\$

4) Total Assets:
$\$ 13,320,000$

$\$ 22,000,000$

$\$ 0,000$

$\$ 35,320,000$

\section{B. Equity:}

\section{1) Investment securities: \\ 2) Common stock:}

3) Retained Earnings:

\section{4) Total Equity:}

\section{$\$ 12,210,000$ \\ $\$ 22,000,000$ \\ $\$ 1,110,000$}

$\$ 35.320,000$

In the above case, A profits of company A is: $\$ 1,110,000$, when the market price of securities increases. Company A didn't revalue value securities. So profits of sale securities were presented in Income statements. The profit estimate of value securities increasing weren't presented in income statements and balance sheet.

For assumption above:

The second case: On 31/12/2012, (the securities are dropping in price in the stock market at the end of the accounting period). Firm A has a debit balance of securities of $1,000,000$ shares. Security price is $\$ 15$ per share. This case, the Vietnamese accounting system states that the prices of securities are adjusted at "market price" when shares are dropped in, this time, the current price of a share is $\$ 15$ per share (the historical cost of a share is $\$ 22$ ). This means that historical cost $>$ current price leads to the firm A making provision for impairment of securities.

Solution 2

The principle of the Vietnamese accounting system follows.

Provision for short term securities investment rate $=$ Total of provision for short term security investments $\mathrm{x}$ [Historical cost of short term security investments - Fair value of short term security investments]: $1,000,000$ shares $x(\$ 15-\$ 22)$ equal to $\$ 7,000,000$.

Table 3: Purchase and Sale of securities at Historical Cost Method.

activities of securities have still increased, simultaneously increasing the retained earnings of $\$ 1,110,000$, instead of $\$ 5,890,000$ as on the balance sheet.

In the Vietnamese accounting system businesses usually apply the historical cost method for inventory securities when they have to present financial statements but this is irrelevant to the fact that the financial statements represent the variability of the security's price which affects the rationality and reliability of the financial statements. The historical cost method does not reflect the volatility of the security value on the financial statements and does not provide the necessary information to investors. Under international accounting standards, the historical cost method is not applied and not presented in financial statements for financial assets.
Problem 2: The match accounting principle of the fair value method: The historical cost principles still have an initial recognition about the asset value so to ensure that the quality of accounting information presented in financial statements is reliable. However, the asset value will be changed under fluctuation in the market on the different phases.

Additionally, the asset value is also worn invisible, because the assets are no longer appropriate in design, decreased quality leading to decline in the asset value. For this reason, the fair value method is applied for asset revaluation when making financial statements. So, if the firms have still applied the historical cost method, the assets would have been longer irrelevant to the market value, especially for the financial assets of Available-for-sale and Held for trading, the firms should apply the 


\begin{tabular}{|l|l|l|l|l|l|l|l|l}
\hline Date & Account and Explanation & Debits & \\
\hline $31 / 12 / 2012$, Provision for short - term securities investment. & Financial expenses. & $\$ 7,000,000$ \\
\cline { 2 - 3 } & Provision for Securities impairment & $\$ 7,000,000$ \\
\hline & & \\
\hline
\end{tabular}

And now,

- Debit balance of Financial expenses:

- Debit balance of cash:

- Debit balance of Securities investments:

$\$ 7,000,000+\$ 555,000=\$ 7,555,0000$

$\$ 13,875,000-\$ 555,000 \$$ equal to $\$ 13,320,000$.

$1,000,000$ shares $x \$ 22$ equal to $\$ 22,000,000$.

1. The result of income statement on 31/12/2012:

- Revenue - Financial activities: (1)

- Financial expenses: (2)

- Profit after Income Tax (3) = (1) - (2)

$\$ 1,665,000$

$\$ 7,555,0000$

$(\$ 5,890,000)$

\section{The result of Balance sheet on 31/12/2012:}

A. Assets:

1). Cash:

2). Investment securities:

3). Provision for short - term investments *:

4) Total Assets:

B. Equity:

1). Investment securities:

2). Common stock:

3). Retained Earnings:

4). Total Equity:

\section{$\$ 13,320,000$ \\ $\$ 22,000,000$ \\ $(\$ 7,000,000)$ \\ $\$ 28,320,000$}

$\$ 12,210,000$

$\$ 22,000,000$

$(\$ 5,890,000)$

$\$ 28,320,000$

In the second case: company A applies Vietnam provision accounting methods, the profits in income statements is loss, and value financial assets on the balance sheet is reduced. Financial statements results did not reflect the true nature of financial asset's value. Actually, the company A still has gained profit from a securities sale. The part of losses is only being a valuation of financial assets in the future. We can see the difference profits in the financial statements when using the fair value method and historical cost to revalue financial assets. The author uses the second method. That is the fair value method below:

Table 4: Purchase and Sale of securities at Historical Cost Method.

fair value method to evaluate the assets at the time of financial statement presentation. The benefit of this method is to get high reliability of the information on the financial statements, and measure the market value of the securities. Besides, the enterprises apply the fair value method for financial risk prevention and effective measurement of the financial assets. For assets on hold for trading, according to the international accounting standards, no provisions for it but use the fair value method for revaluation through loss/profit. Thus, the assets always guarantee their real value and the high relevance and reliability in the financial statements are better. We may consider the results in the financial statements through the above assumptions as follows:

In regards to the results presented on income statements, there are two items to be recorded concerning the two different profit parts; these profits are from financial activities and other comprehensive incomes. These two items are important for analyzing financial statements and are helpful to investors because they can easily see where the profits come from: Stock trading activities or from the gains or losses that come from different levels of the asset prices. Specifically, when a business sells its securities it gets a profit of $\$ 1,110,000$, because the stock prices increase at this time and an unrealized profit becomes $\$ 8,000,000$ due to increase in security price in the market at the time of financial statement presentation. This information is very important for the stock investors, because they can immediately see the future profits given by their stock inventory. So, they can make decisions in the investment or not.

For the balance sheet, the inventory item clearly presents the security value when the security prices increase in the market. Specifically, when the security prices in the market were increased to $\$ 30$ in 31/12/2012, on the short-term stock investment item the value also changes to $\$ 30,000,000$. These results indicate that security prices in the market are favorable for investors and if the securities are sold at this time, they will get profits of $\$ 8,000,000$. For the equity item, it also shows two separate items that are retained earnings and other comprehensive income. These items help the investors to clearly see the capital source that increased from security activities that have been executed and the capital source that increased from security activities but that have not been executed yet. From this information investors may evaluate the potential value and profitability of the securities in the future such as: the profit brought from security activities is $\$ 1,110,000$, the unrealized profit is $\$ 8,000,000$.

When the security prices fall, the results in the financial statements also show the security trading effectiveness and future damages. The income statements show the increased profits and lost profits, from this information, the investors can avoid the financial risks. Because two items are separate, the investors see the damage of the inventory security and can use the accounting hedge method or hedge derivative instruments (usage of the hedge derivative instruments will be studied in the next topic). Based on the above hypothesis, the profits from financial activities are $\$ 1,110,000$ and the unrealized loss is $\$ 7,000,000$. The realized profits from financial activities show that the company still gets profits and is very productive in the financial year. The unrealized loss is in the information that the investors are interested in for making reasonable and timely decisions. For the capital source, the inventory security value is reduced to $\$ 15,000,000$ as the market prices are in the item of short-term investment securities. This value indicates that security prices in the market pose a disadvantage for the investors and the investors know the real value of financial assets. This is useful information for financial analyses as a means of assessing the results of business assets. For the capital source, two separate items also help the investors to see the realized profits and unrealized losses.

Problem 3: The results of difference between the use of historical cost method and fair value method: The results in Table 6 show the 


\begin{tabular}{|c|c|}
\hline Date & Account and Explanation \\
\hline \multirow{2}{*}{$\begin{array}{l}\text { - The first case: } 31 / 12 / 2012 \text {, the quoted price is higher than } \\
\text { historical Common securities:. } \\
\text { cost. * Write - up. }\end{array}$} & Common securities: \\
\hline & Other comprehensive incom \\
\hline \multirow{2}{*}{$\begin{array}{l}\text { - The second case: } 31 / 12 / 2012 \text {, the quoted price is less than } \\
\text { historical cost. *Write - down. }\end{array}$} & Other comprehensive \\
\hline & Common securities \\
\hline \multicolumn{2}{|c|}{$\begin{array}{l}\text { Debit balance of securities is } \$ 30,000,000:(\$ 22,000,000+\$ 8,000,000) \text {. } \\
\text { - The result of first case: }\end{array}$} \\
\hline \multicolumn{2}{|l|}{ 1. The result of income statement on $31 / 12 / 2012$ : } \\
\hline $\begin{array}{l}\text { - Revenue - Financial activities: (1) } \\
\text { - Financial expenses: (2) } \\
\text { - Profit after Income Tax (3)=(1) - (2) } \\
\text { - Other Comprehensive Income (gain/loss): (4) } \\
\text { - Total Profit: }(5)=(3)+(4) \text { : }\end{array}$ & $\begin{array}{l}\$ 1,665,000 \\
\$ 555,0000 \\
\frac{\$ 1,110,000}{\$ 8,000,000} \\
\$ 9,110,000\end{array}$ \\
\hline
\end{tabular}

2. The result of Balance sheet on $31 / 12 / 2012$ :

A. Assets:

1). Cash:

2). Investment securities:

3). Provision for short - term investments *:

4) Total Assets:

B. Equity:

1). Investment securities:

2). Common stock:

3). Retained Earnings:

4). Net Other Comprehensive Income. (Gain/loss):

4). Total Equity:

- The result of second case:

* Debit balance of securities is $\$ 15,000,000$ : $(\$ 22,000,000-\$ 7,000,000)$.

1. The result of income statement on 31/12/2012:

- Revenue - Financial activities: (1)

- Financial expenses: (2)

- Profit after Income Tax (3) = (1) - (2)

- Other Comprehensive Income (gain/loss): (4)

- Total Profit: $(5)=(3)+(4)$ :

$\$ 13,320,000$

$\$ 30,000,000$

$\underline{000,000}$

$\$ 43,320,000$

$\$ 12,210,000$

$\$ 22,000,000$

$\$ 1,110,000$

$\$ 8,000,000$

$\$ 43,320,000$

\section{$\$ 1,665,000$ \\ $\$ 555,0000$ \\ $\$ 1,110,000$ \\ $(\$ 7,000,000)$ \\ $(\$ 5,890,000)$}

2. The result of Balance sheet of $31 / 12 / 2012$ :

\section{A. Assets:}

1). Cash:

2). Investment securities:

3). Provision for short - term investments *

4) Total Assets:

B. Equity:

1). Investment securities:

2). Common stock:

3). Retained Earnings:

4). Net Other Comprehensive Income. (Gain/loss):

4). Total Equity:

The analysis of data and results of the financial statements shown above demonstrates the interactive impacts to the financial markets through investors. The financial information on the financial statements plays an important role in financial analysis and the provision of economic targets for the investors to evaluate the profitability or the financial health of a quoted company on the stock market. To analyze and clarify how these factors affect the stock market, as well as investors' comments on Vietnam's financial statements and the solutions for Vietnam's stock market development will be presented in the discussion part.

Table 5: Purchase and Sale of securities at Fair value method.

difference in percentage rate in a scenario whereby there is an increased security's price. Using the historical cost method, the difference in profit is $88 \%$, when security prices reduce the total income there is no difference $(0 \%)$. However, the income after tax has a big difference (631\%) and some items also have differences [30].

The results of the Table 7 above, show that a scenario whereby there is a decreased security's price, the total assets and total capital have no difference when using two methods $(0 \%)$. However, there is a big difference in other items such as: Investment securities with a difference of $47 \%$, Retained Earnings with a big difference of $631 \%$ and Net Other Comprehensive Income (gain/loss) with a difference of 100 $\%$. In a scenario whereby there is an increased security's price, there are differences in total assets and total capital (18\%), these differences are due to that the historical cost method does not recognize the increased securities. Some items in the balance sheet also have differences such as: Investment securities with a difference of $47 \%$, Retained Earnings with a difference of $631 \%$ but these basic differences have a large effect on the quality and reliability of financial statements. The items presented 
in financial statements are impact factors of the financial analysis results that was done by investors, this part will be elaborated further in problem 4 [31].

Problem 4: The items presented in the financial statements are analysis of security targets: The accounting information presented in financial statements provides some basic elements to be used by investors, these elements assist in assessing the profitability of investing in securities and assist in analyzing indicators related to investments in the stock market, investors base their decisions upon these indicators. The basic criterion used to analyze security investment is as follows:

* Assuming usage of profitability indicators and usage of the company A's assets, the financial statement is as follows:

Return on Assets (ROA) $\mathrm{H}=\frac{\$ 1,110,000}{\$ 35,320,000} \times 100 \%=3 \%$

Return on Assets $(\mathrm{ROA}) \mathrm{F}=\frac{\$ 1,110,000}{\$ 43,320,000} \times 100 \%=2.6 \%$

\section{$\checkmark$ In the case of a decreased security's price:}

$$
\text { Return on Assets }(\mathrm{ROA})_{\mathrm{H}}=\frac{\$ 5,890,000}{\$ 28,320,000} \times 100 \%=21 \%
$$$$
\text { Return on Assets }(\mathrm{ROA})_{\mathrm{F}}=\frac{\$ 1,110,000}{\$ 28,320,000} \times 100 \%=4 \%
$$

Through the above analyzed data it shows that there is a difference from the result of return on assets. In the case of increased security prices, the return on assets ROA $(\mathrm{H})$ is equal to $3 \%$ that means:

ROA provides the investors with information about the profits generated from the investment capital (or assets). The ROA for jointstock firms has a big difference and depends on business fields. That is why when using ROA to compare firms, it is better to compare each company's ROA over years and compare it among similar firms. Assets of a company are formed from loan capital and equity both funds are used to finance the company's activities. The effect of the transfer of investment capital into the profit is shown by ROA. The higher ROA is better because the company is earning more money on less investment. The analyzed data above shows that there is a difference from the result of return on assets. In the case of security price increases, the profitability ratio of $\mathrm{ROA}(\mathrm{H})$ is equal to $3 \%>\mathrm{ROA}(\mathrm{F})$ is equal to $2,6 \%$ that means: if the Company uses this method, the ROA is higher than ROA of the fair value method. Nevertheless, this ROA $(H)$ is unreal because the company ignored the increased security's value when making financial statements. In the case of a decreased security's price, ROA $(\mathrm{H})$ and ROA (F) have a big difference such as: ROA $(\mathrm{F})$ is equal to $-21 \%$ much less than ROA $(\mathrm{H})$ is equal to $4 \%$. If the investors use the result of ROA $(\mathrm{H})$ to make decisions in security investment, they will get many risks. This result reflects unrealistic and not highly reliable information as the above analysis. For $\mathrm{ROA}(\mathrm{H})$ is equal to $4 \%$, showing that the company still gets profits but only has unrealized losses due to decreased price of inventory security.

\section{Conclusions}

From the problems mentioned above, it shows that the fair value method is always appropriate and contains high reliability of financial information. The information provided by financial statements brings great benefits to investors; for businesses have reliable information for financial analysis. Therefore investors have a basis for making investment strategies that bring high effectiveness to the economy. The international standard system emphasizes that the fair value method should be applied for the hedge financial activities or revaluation of financial assets.

The results also show that the accounting system is very important for the application of collecting data and incidental business data processing. In this phase, it is necessary for firms to apply appropriate accounting methods for economic transactions to ensure that the accounting information correctly reflects the economic nature. The accounting system affects the chain, the chain starts from recognizing, processing and presenting the financial statement and eventually released to the public. When the financial statements are released to the public, it is a period of great influence for the stock market through decisions taken by those who use financial statements. Thus, the use of the fair value accounting method should be comprehensively and fully applied. The Vietnamese accounting system needs to be reviewed, it lacks fair value accounting instruments that can be applied by firms; this has a big impact on the stock market. Presently, Vietnam's stock market has developed in two areas of Hanoi and Ho Chi Minh City and has about 500 quoted local firms; the number of participating firms is large enough to impact the Vietnam's stock market [32]. Therefore, the Vietnamese accounting system needs a comprehensive reform and to quickly complete accounting standards of financial instruments; these are a set of standards that are very important for firms to apply on the financial hedge and very important to apply to the category of financial assets and liability assets. The Vietnamese stock market has developed since the year 2000 up to now, more than a decade, but there are still no financial instruments of accounting standards applicable for this field. In today's environment, the Vietnamese Accounting System should apply the fair value method for financial asset evaluation instead of using the historical cost method to evaluate financial assets as currently [33]. This helps investors to get full and correct information to make

\begin{tabular}{|c|c|c|c|}
\hline \multirow[b]{2}{*}{ Items } & \multicolumn{2}{|c|}{ Results } & \multirow{2}{*}{$\begin{array}{l}\text { Different ratio } \\
((\mathrm{H}-\mathrm{F}) / \mathrm{F}) \times 100 \%\end{array}$} \\
\hline & $\begin{array}{c}\text { Historical cost } \\
\text { method }(\mathrm{H})\end{array}$ & $\begin{array}{l}\text { Fair value } \\
\text { method (F) }\end{array}$ & \\
\hline \multicolumn{4}{|l|}{$\begin{array}{l}\text { In the case of an } \\
\text { increased price. }\end{array}$} \\
\hline $\begin{array}{l}\text { - Revenue - Financial } \\
\text { activities. }\end{array}$ & $1,665,000$ & $1,665,000$ & $0 \%$ \\
\hline - Financial expenses. & 555,000 & 555,000 & $0 \%$ \\
\hline Profit After Income Tax & $1,110,000$ & $1,110,000$ & $0 \%$ \\
\hline $\begin{array}{l}\text { Other comprehensive } \\
\text { income. }\end{array}$ & & $8,000,000$ & $-100 \%$ \\
\hline Total profits & $1,110,000$ & $9,110,000$ & $-88 \%$ \\
\hline \multicolumn{4}{|l|}{$\begin{array}{l}\text { In the case of a } \\
\text { decreased price. }\end{array}$} \\
\hline $\begin{array}{l}\text { - Revenue - Financial } \\
\text { activities. }\end{array}$ & $1,665,000$ & $1,665,000$ & $0 \%$ \\
\hline - Financial expenses. & $7,555,000$ & 555,000 & $1261 \%$ \\
\hline Profit After Income Tax & $(5,890,000)$ & $1,110,000$ & $-631 \%$ \\
\hline $\begin{array}{l}\text { Other comprehensive } \\
\text { income. }\end{array}$ & & $(7,000,000)$ & $-100 \%$ \\
\hline Total profits & $(5,890,000)$ & $(5,890,000)$ & $0 \%$ \\
\hline
\end{tabular}

Unit: \$

Table 6: Comparison of income.

http://www.thesaigontimes.vn/Home/taichinh/chungkhoan/83489/Bao-cao-tai-chinh-nen-huong-toi-nha-dau-tu.html 


\begin{tabular}{|c|c|c|c|}
\hline \multirow{2}{*}{ Items } & \multicolumn{2}{|c|}{ Results } & \multirow{2}{*}{$\begin{array}{l}\text { Different ratio } \\
((\mathrm{H}-\mathrm{F}) / \mathrm{F}) \times 100 \%\end{array}$} \\
\hline & $\begin{array}{l}\text { Historical cost } \\
\text { method }(\mathrm{H})\end{array}$ & $\begin{array}{l}\text { Fair value } \\
\text { method (F) }\end{array}$ & \\
\hline \multicolumn{4}{|c|}{$\begin{array}{c}\text { In the case of an increased } \\
\text { price. }\end{array}$} \\
\hline \multicolumn{4}{|l|}{ Assets. } \\
\hline - Current assets. & $13,320,000$ & $13,320,000$ & $0 \%$ \\
\hline - Investment securities. & $22,000,000$ & $30,000,000$ & $-27 \%$ \\
\hline \multicolumn{4}{|l|}{$\begin{array}{l}\text { - Provision for short - term } \\
\text { investments * }\end{array}$} \\
\hline Total assets. & $35,320,000$ & $43,320,000$ & $-18 \%$ \\
\hline \multicolumn{4}{|l|}{ Equity. } \\
\hline - Investment capital. & $12,210,000$ & $12,210,000$ & $0 \%$ \\
\hline - Common stock & $22,000,000$ & $22,000,000$ & $0 \%$ \\
\hline Retained Earnings & $1,110,000$ & $1,110,000$ & $0 \%$ \\
\hline $\begin{array}{l}\text { Net Other Comprehensive } \\
\text { Income. (Gain/loss) }\end{array}$ & & $8,000,000$ & $-100 \%$ \\
\hline Total Equity. & $35,320,000$ & $43,320,000$ & $-18 \%$ \\
\hline \multicolumn{4}{|l|}{$\begin{array}{c}\text { In the case of a decreased } \\
\text { price. }\end{array}$} \\
\hline \multicolumn{4}{|l|}{ Assets. } \\
\hline - Current assets. & $13,320,000$ & $13,320,000$ & $0 \%$ \\
\hline - Investment securities. & $22,000,000$ & $15,000,000$ & $47 \%$ \\
\hline $\begin{array}{l}\text { - Provision for short - term } \\
\text { investments * }\end{array}$ & $(7,000,000)$ & & \\
\hline Total assets. & $28,320,000$ & $28,320,000$ & $0 \%$ \\
\hline \multicolumn{4}{|l|}{ Equity. } \\
\hline - Investment capital. & $12,210,000$ & $12,210,000$ & $0 \%$ \\
\hline - Common stock & $22,000,000$ & $22,000,000$ & $0 \%$ \\
\hline Retained Earnings & $(5,890,000)$ & $1,110,000$ & $-631 \%$ \\
\hline $\begin{array}{l}\text { Net Other Comprehensive } \\
\text { Income. (Gain/loss) }\end{array}$ & & $(7,000,000)$ & $-100 \%$ \\
\hline Total Equity. & $28,320,000$ & $28,320,000$ & $0 \%$ \\
\hline
\end{tabular}

Unit: \$

Table 7: Comparison of balance sheets.

effective investments. According to the plan of the Ministry of Finance, from now to the year 2015 the standard system will be completed. In particular, for the financial instruments standard system, Vietnam will study the basic principles of international standards, and then reevaluate to set up standards specific to Vietnam. This is a good sign for the Vietnamese stock market; there will be major changes in the completeness of accounting standards this change will ensure that appropriate accounting principles are used towards the economy and international rules $[34,35]$.

${ }^{2}$ In fact, the implementation of Vietnamese accounting standards meets great difficulties, because in the accounting standard system, there are many guidance circulars which the accounting industry often follows without consulting accounting standards consequently this leads the accounting industry to become passive and compliant. In the opinion of Mr. Bui Hoang Hai, Deputy Director under the Release Management Department of the State Securities Committee, Vietnam now has 26 Vietnamese accounting standards, but in reality, the supervision of full implementation of 26 standards is difficult. So according to Mr. Hai's opinion, the implementation of standards is not more important than actually keeping the enterprises under discipline in the implementation of standards, so that investors are not misled into believing in the information presented on the enterprises financial statements. He also gives examples of administrative decisions for governance. Mr. Dang Thai Hung, Director of the Accounting Regime Department of the Ministry of Finance said that: for treatment of the exchange rate difference, the accounting standards allow allocation into the financial activity costs but in accordance with Circular No. 201/2009/C-MOF the allocation is made in 5 years. Hence, the enterprises will not be lost if following this circular. Currently, the Ministry of Finance has changed the above circular and issued the same as in the accounting standards to avoid the aforesaid phenomenon. But the accounting policies issued by micro- managers have an impact on the stock market through investors. In particular, the biggest impacts are that the financial analysis targets are based on the items on financial statements of quoted firms. Therefore, the financial statements of the enterprises with high reliability and reasonability will bring benefits to the economy or stock market. If financial statements are inappropriate and lack reliability subsequently they will constrain the economy and the stock market. It will impact any economy or nation but not only one country, such as Vietnam's economy.

\section{References}

1. Laux C, Leuz C (2009) Did Fair-Value Accounting Contribute to the Financial Crisis? National Bureau of Economic Research, NBER Working Paper 15515.

2. Ryan SG (2008) Fair Value Accounting: Understanding The Issues Raised by the Credit Crunch. Council of Institutional Investors, New York University, NY USA.

3. Historical Cost and Fair Value Accounting: Relevance and Reliability Revisited

4. International Accounting Standard (2011), IAS 39 (Financial Instruments: Recognition and Measurement).

5. International Accounting Standard Board "IASB" (2012) IFRS 9: Financial Instruments.

6. International Accounting Standard (2003) IAS 32 (Financial Instruments: Presentation).

7. International Accounting Standard (2005) IFRS 7 (Financial Instruments: Disclosures).

8. International Accounting Standard (2008) IAS 40 (Investment Property).

9. International Accounting Standard (1991) IAS 30 (Disclosures in the Financial Statements of Banks and Similar Financial Institutions).

10. International Accounting Standard (2008) IAS 38 (Intangible Assets).

11. International Accounting Standard (2008) IAS 16 (Property, Plant and Equipment).

12. International Accounting Standard (2008) IAS 2 (Inventories).

13. International Accounting Standard Board "IASB" (2008) IAS 39: Financial Instruments: Recognition And Measurement.

14. Bischof J, Elbert M (2007) IAS 39 and basis in rick perception of financial instruments. Universitat Mannheim, Deutsche, Germany.

15. Horton J, Macve R (2000) 'Fair value' For Financial Instruments: How Erasing Theory is leading To Unworkable Global Accounting Standard Performance Reporting. The Australian Accounting Reviews 11: 26-39.

16. Ow Yong KK, Fair Value Accounting: SFAS 157 and IAS 39 2of 6.

17. Ministry of Finance (2009) Circular No. 210/2009/C -MOF, 06/11/2007.

18. Minister of Finance (2001) Vietnam accounting standard 2 (Inventories), $31 / 12 / 2001$.

19. Minister of Finance, (2001), Vietnam accounting standard 3, Tangible fixed assets, 31/12/2001.

20. Minister of Finance (2005) Vietnam accounting standard 22, Disclosures in the Financial Statements of Banks and Similar Financial Institutions, 15/02/2005.

21. Minister of Finance (2003) Vietnam accounting standard 5, Investment property, 30/12/2003.

22. Minister of Finance (2001) Vietnam accounting standard 4, Intangible fixed assets, 30/12/2003.

23. Ministry of Finance (2006) Decision No. 15/2006/QD-MOF, 15/7/2006. 24. Ministry of Finance (1995) Decision No. 1141-TC/Q Đ/C ĐKT, 1/ 11/1995. 25. Ministry of Finance (2001) Decision No. 149/2001/Q Đ-BTC, 31/12/2001. 26. Ministry of Finance (2002) Decision No. 165/2002/ Q Đ-BTC, 31/12/2002. 27. Ministry of Finance (2003) Decision No. 234/2003/ Q Đ-BTC, 31/12/2003. 
28. Ministry of Finance (2005) Decision No. 12/2005/ Q Đ-BTC, 15/2/2005.

29. Ministry of Finance (2005) Decision No. 100/2005/ Q Đ-BTC, 18/12/2005.

30. PricewaterhouseCoopers (2008) Similarities and Differences: A Comparison of IFRS and Thai GAAP, Vietnamese GAAP, Cambodian GAAP and Laos GAA, Vietnam.

31. www.acsbcanada.org
32. http://www.thesaigontimes.vn/Home/taichinh/chungkhoan/83489/Bao-cao-taichinh-nen-huong-toi-nha-dau-tu.html

33. http://www.investopedia.com/terms/h/historical-cost.asp\#ixzz2FGfBbQQo

34. http://business-accounting-guides.com/historical-cost/

35. http://en.stockbiz.vn/News/2012/1/3/262166/vietnam-stock-market-loses-over10b-of-capitalization-in-2011.aspx 